\title{
Conservation status of Sorbus cuneifolia (Rosaceae), Llangollen whitebeam
}

Timothy C.G. Rich*, Libby Houston, Andrew Goodwin, Victoria Morgan, Sarah Bird, Rhun Jones, Richard May, David Shiel, Ros Stockdale.

*Corresponding author: Timothy C.G. Rich, email: tim_rich@sky.com

This pdf constitutes the Version of Record published on $13^{\text {th }}$ August 2019

\begin{abstract}
A survey of the rare tree Sorbus cuneifolia T.C.G. Rich (Rosaceae), Llangollen whitebeam, was undertaken to inform a conservation programme as part of a collaborative project between Chester Zoo, the Clwydian Range and Dee Valley AONB, Denbighshire County Council and Natural Resources Wales. A field survey in September 2017 found 307 trees at Creigiau Eglwyseg (with another nine which were either S. cuneifolia or S. rupicola), and 8 trees at Blodwel Rock. The increase from 240 trees recorded in 1987 was attributed to differences in recording, though it has gone from Castell Dinas Bran. Tree growth indicators at Creigiau Eglwyseg show that the population is healthy with a wide range of tree sizes present and $66 \%$ of trees fruiting. Sorbus cuneifolia was confirmed as of conservation status 'Endangered'; there are no immediate requirements for its conservation.
\end{abstract}

Keywords: endemic; IUCN threat status; England; Wales; Hedlundia cuneifolia

\section{Introduction}

In 2017 a survey of the rare tree Sorbus cuneifolia T.C.G. Rich, Llangollen whitebeam, was undertaken to inform a conservation programme as part of a collaborative project between Chester Zoo, the Clwydian Range and Dee Valley AONB, Denbighshire County Council and Natural Resources Wales. The aim of this paper is to summarise the results of the survey and assess changes in population since 1987; full details can be found in Rich et al. (2017).

Sorbus cuneifolia is a rare tree endemic to Britain (Rich et al., 2010). It was first recorded under $S$. aria from Castell Dinas Bran (as $S$. hybrida) in Hudson (1798) and then by C.C. Babington as $S$. aria $\beta$ intermedia in Smith (1843). It was then generally recorded under $S$. anglica Hedl. until formally described in Rich \& Proctor (2009). It is known from two sites. The main site is on the limestone cliffs of Creigiau Eglwyseg, Llangollen, Denbighshire (v.c. 50), Wales, where Morgan (1987) recorded 239 trees scattered over $c .7 \mathrm{~km}$ of cliffs and one tree on Castell Dinas Bran. In 2011, a second site with two plants was discovered at Blodwel Rock, Llynclys, Shropshire (v.c. 40), England (Rich \& Whild, 2012). 


\section{Methods}

Identification

Sorbus cuneifolia is characterised by the obovate, regularly lobed leaves with cuneate bases and greenish-white tomentum underneath, and small red fruits (Fig. $1 a-c)$.
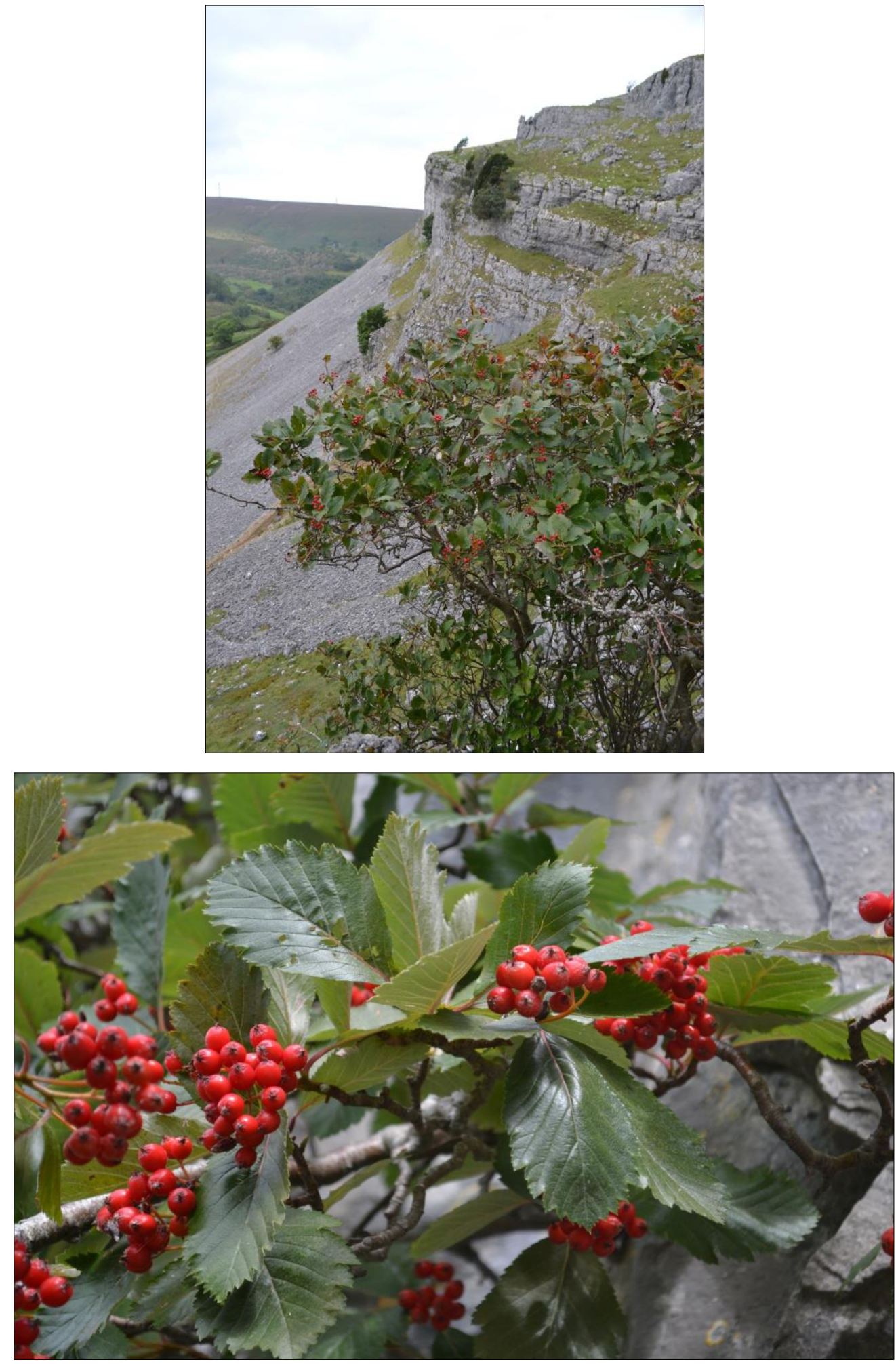


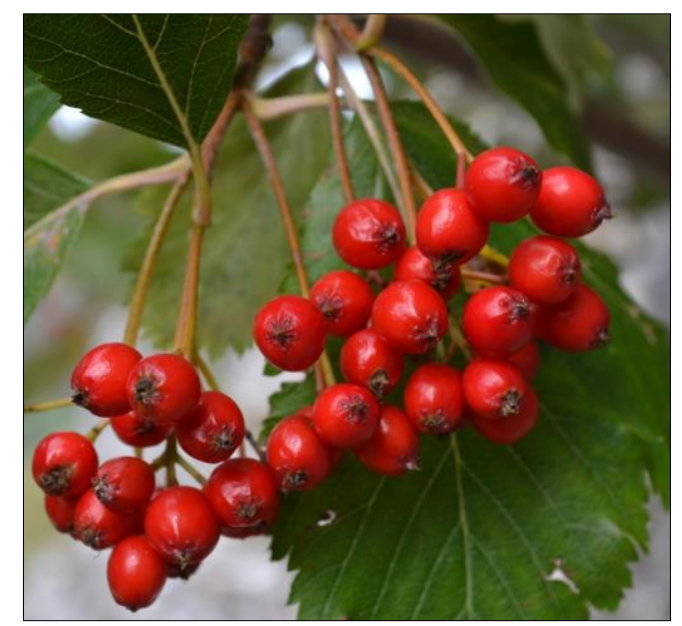

Figure 1a-c. Images of Sorbus cuneifolia.

Sorbus rupicola Hedl.(Rock Whitebeam) and S. aucuparia L. (Mountain Ash) also occur at Creigiau Eglwyseg, and $S$. anglica (English Whitebeam) and $S$. torminalis (Wild Service-tree) at Blodwel Rock. Sorbus cuneifolia is only likely to be confused with $S$. anglica which differs in the elliptic leaves with broad rounded bases, or with $S$. rupicola which has oblong-obovate, unlobed leaves with dense white tomentum underneath and big red fruits (Fig. 2). Of the 751 Sorbus trees recorded, only nine individuals at Creigiau Eglwyseg could not be identified as either $S$. cuneifolia or $S$. rupicola where they could not be seen clearly.

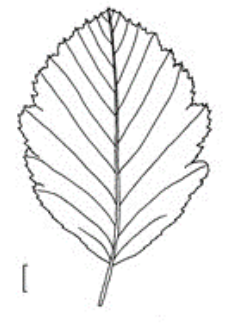

S. anglica

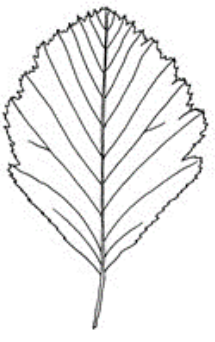

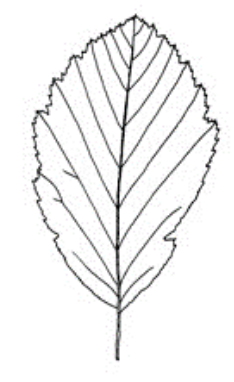

S. cuneifolia
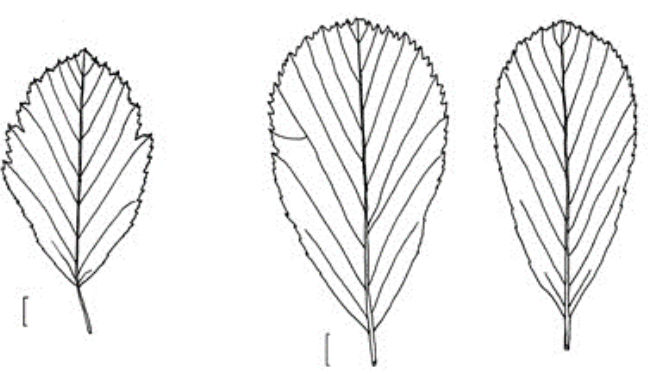

S. rupicola

Figure 2. Comparison of leaf shapes of Sorbus anglica, $\mathbf{S}$. cuneifolia and $\mathbf{S}$. rupicola. Scale bars $=1 \mathrm{~cm}$.

Field survey 2017

The field survey was carried out 4-7 September 2017 by Tim Rich and Libby Houston. Additional records were provided by Sarah Bird and Rhun Jones.

At Creigiau Eglwyseg (Fig. 3), trees were recorded by eye or with the aid of binoculars or camera. Each tier of cliffs (sometimes there were 5 or 6 tiers) was assessed from below, or where the ledges between tiers were too steep or narrow, two tiers of cliffs were recorded from below. Some ledges are very narrow and steep, but no rope access was undertaken. 


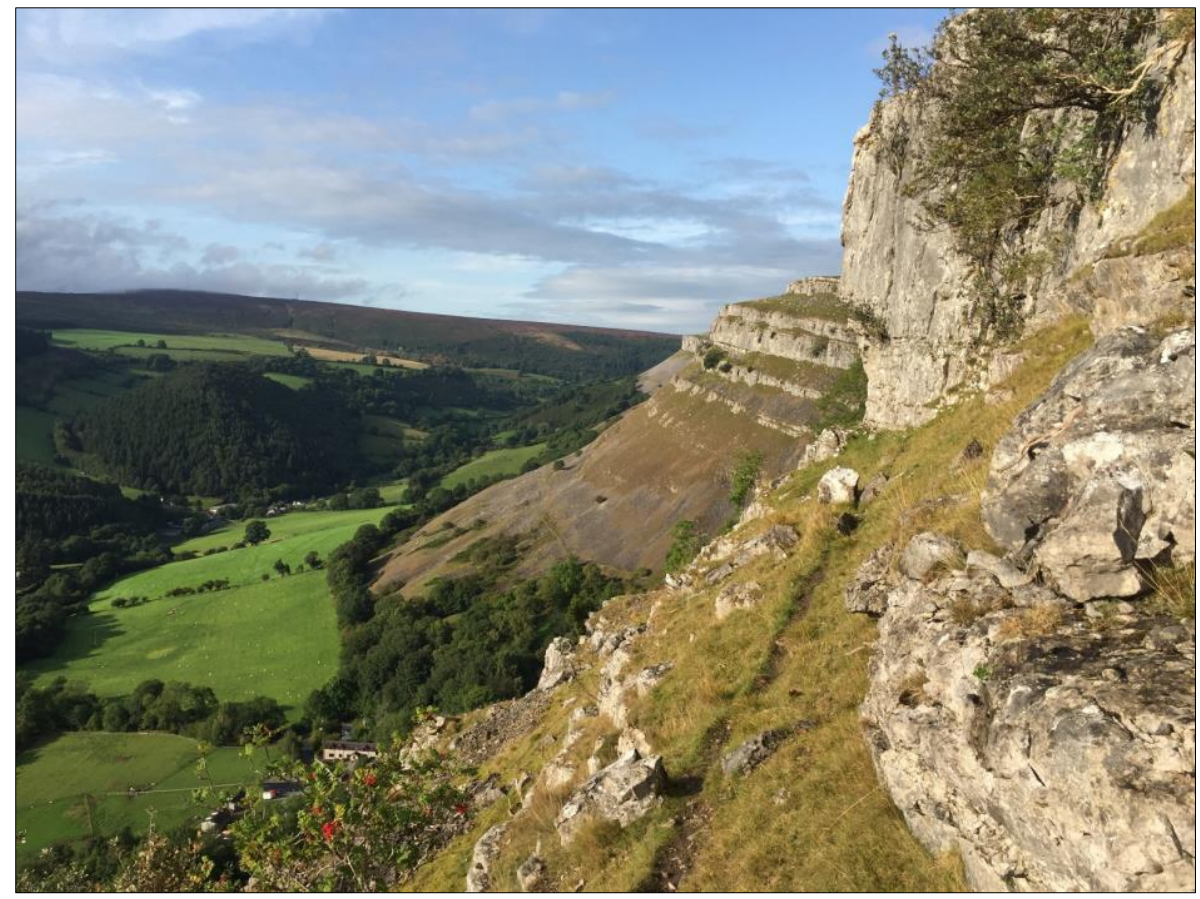

Figure 3. Typical habitat of Sorbus cuneifolia at Creigiau Eglwyseg.

At Blodwel Rock (Fig. 4), the trees were searched from the footpath above the cliff by pushing through the dense scrub on the edge and looking down; the scrub made seeing trees below difficult and coverage of these rocks was felt to be poor.

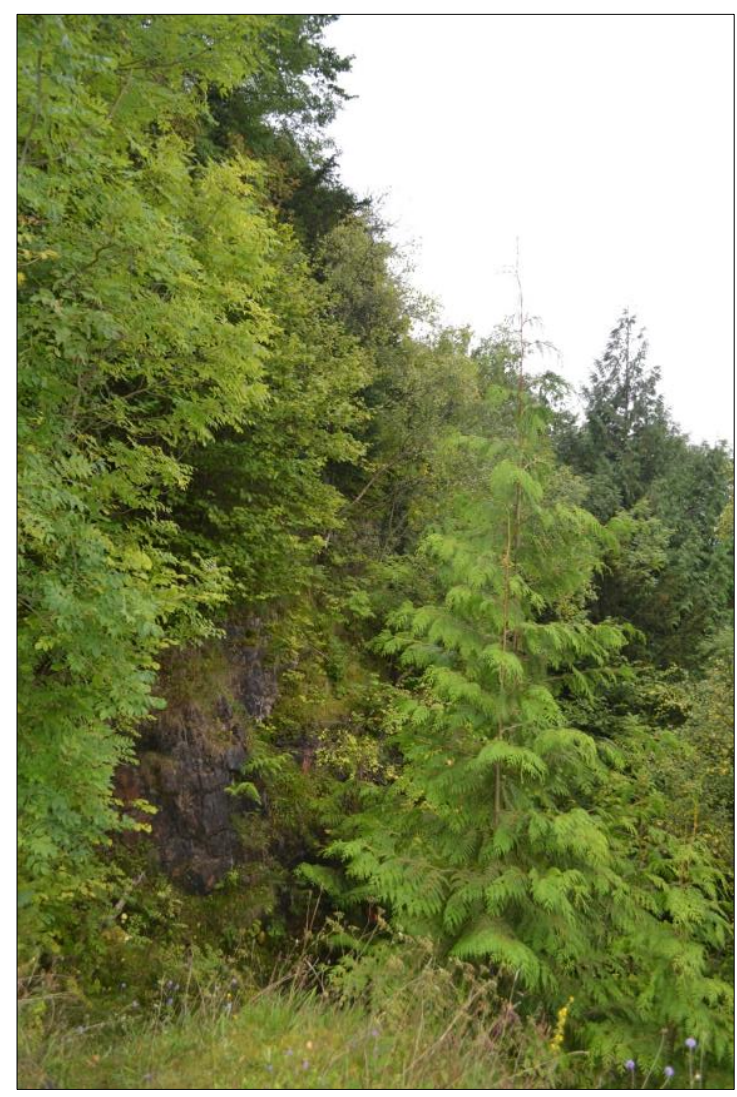

Figure 4. Typical habitat of Sorbus cuneifolia at Blodwel Rock. 


\section{Population census}

Each tree was given a unique survey number, and GPS grid references were taken at the base of the cliff underneath it using a handheld Garmin Etrex unit, usually with a unit-reported 'accuracy' of 3-6 m; in practice they are probably not this accurate.

\section{Tree growth indicators}

Tree heights were estimated to the nearest $0.5 \mathrm{~m}$ up to $4 \mathrm{~m}$, and then to nearest metre above that. They were recorded as either 'maiden' with only 1 stem or trunk, or as 'coppice' where multiple stems were present (these are naturally coppiced trees rather than being cut). The presence or absence of fruit was noted. It was not possible to recorded tree girth as we have previously done to get a proper age estimate (e.g. Houston et al. 2008) as trees were inaccessible on the cliffs.

\section{Comparison of Creigiau Eglwyseg population with 1987 survey}

Vicky Morgan surveyed $S$. cuneifolia at Creigiau Eglwyseg on 14-15 May, 4-6 August and 18 September 1987 (Morgan 1987) by walking along the cliffs and counting trees from vantage points, marking approximate positions of trees on distant photographs of the crags (not every tree was individually marked on the photographs). A more restricted area was surveyed and the narrow ledges were not accessed to the same extent as in 2017.

The comparison was made first by comparing the general areas in which trees were seen in 2017 with those marked on the 1987 photos, and second, comparing numbers of trees recorded in the same sections of cliff.

\section{Results}

\section{Field survey 2017}

The distribution of the 307 trees of $S$. cuneifolia at Creigiau Eglwyseg is shown in Fig. 5a-d. It occurs throughout the site with particular concentrations on the larger crags at the centre, but was very rare at the southern end. Sorbus rupicola also occurred throughout Creigiau Eglwyseg (303 trees recorded, possibly the largest population in the British Isles) but differed in frequency locally, whilst $S$. aucuparia was more patchy in distribution, showing a preference for the NW facing crags in the centre of the site and was abundant at the north end.

The distribution of the 8 trees of $S$. cuneifolia scattered along the cliffs at Blodwel Rock is shown in Fig. 6 . The increase from 2 to 8 trees is due to previous recording error with some trees mistaken for $S$. anglica ( $S$. cuneifolia was not known at the site at the time); a survey using rope access is still required to assess the population properly. In addition, five trees of $S$. anglica and one $S$. torminalis were present.

With very few exceptions, $S$. cuneifolia trees were rooted directly into the cliffs, usually at least $1.5 \mathrm{~m}$ up from the bottom of each cliff up to the very exposed top edges. One $S$. cuneifolia was found in big block-boulder scree with its top grazed by sheep, one was found on a large boulder off-set from the cliffs, and another young tree occurred in tall Vaccinium myrtillus fenced from sheep. A comparison of the relative positions of $S$. cuneifolia and $S$. rupicola on the cliffs at Creigiau Eglwyseg shows both average about $7.3 \mathrm{~m}$ up from the cliff base (range $1.5 \mathrm{~m}$ to $30 \mathrm{~m}$ or 
more, $n=263$ ) with no significant difference between them showing neither prefers relatively more sheltered or more exposed conditions lower or higher on the cliffs ( $t$ test, $\mathrm{p}=0.85$ ).

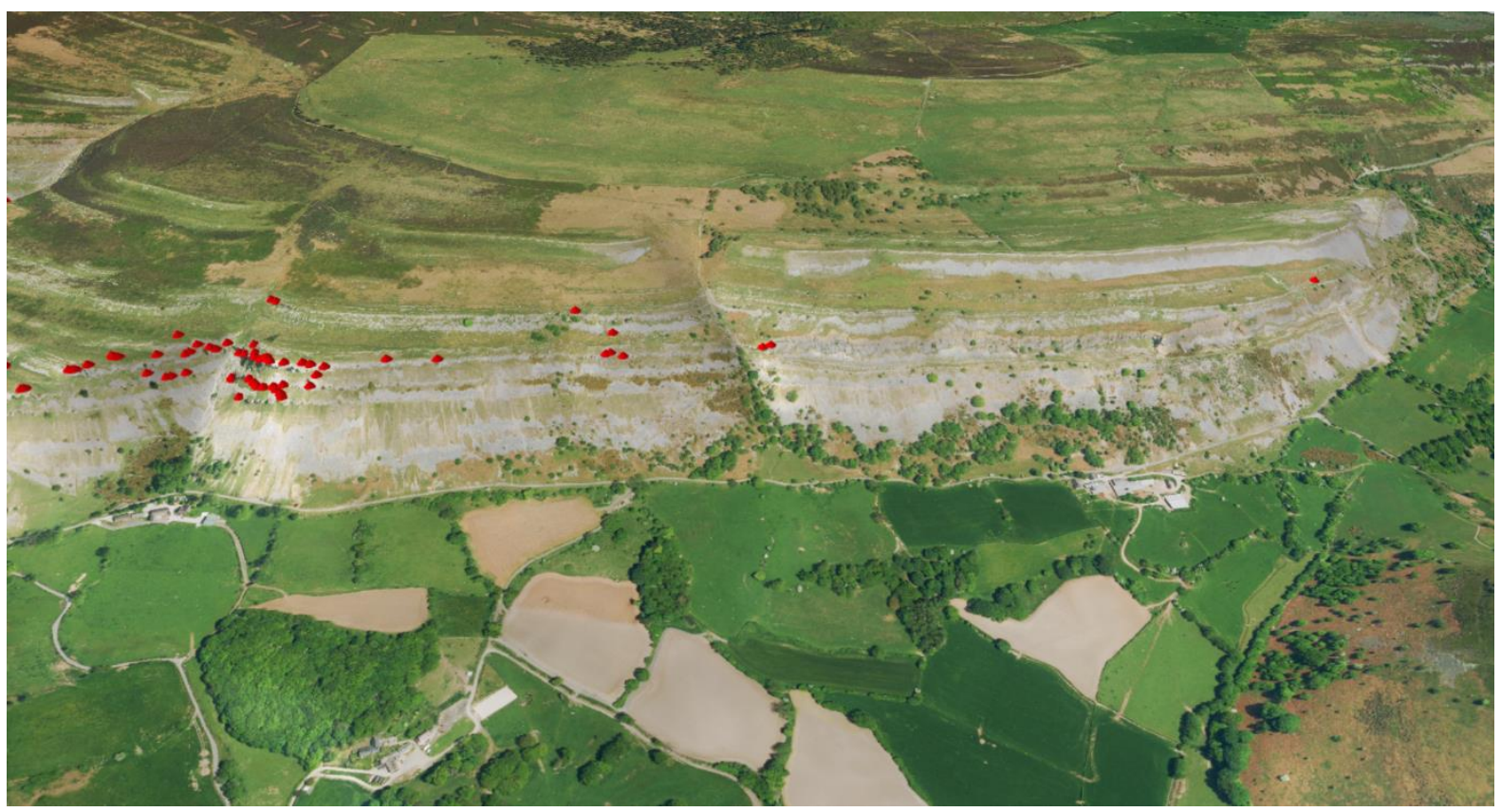

a. Trevor Rocks to Dinbren Uchaf.

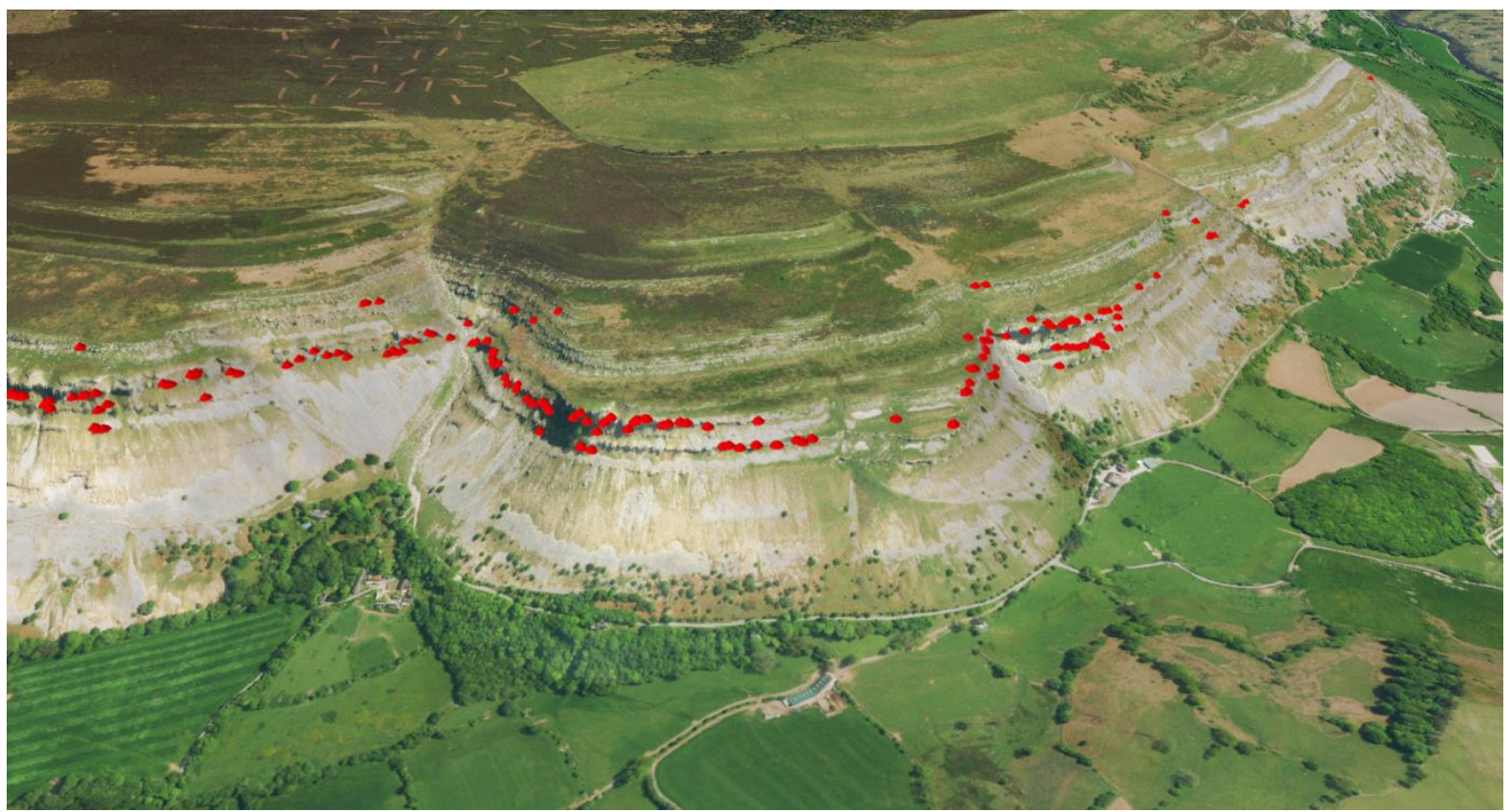

b. Dinbren Uchaf to mid Craig Tri-Naid-y-Gath. 


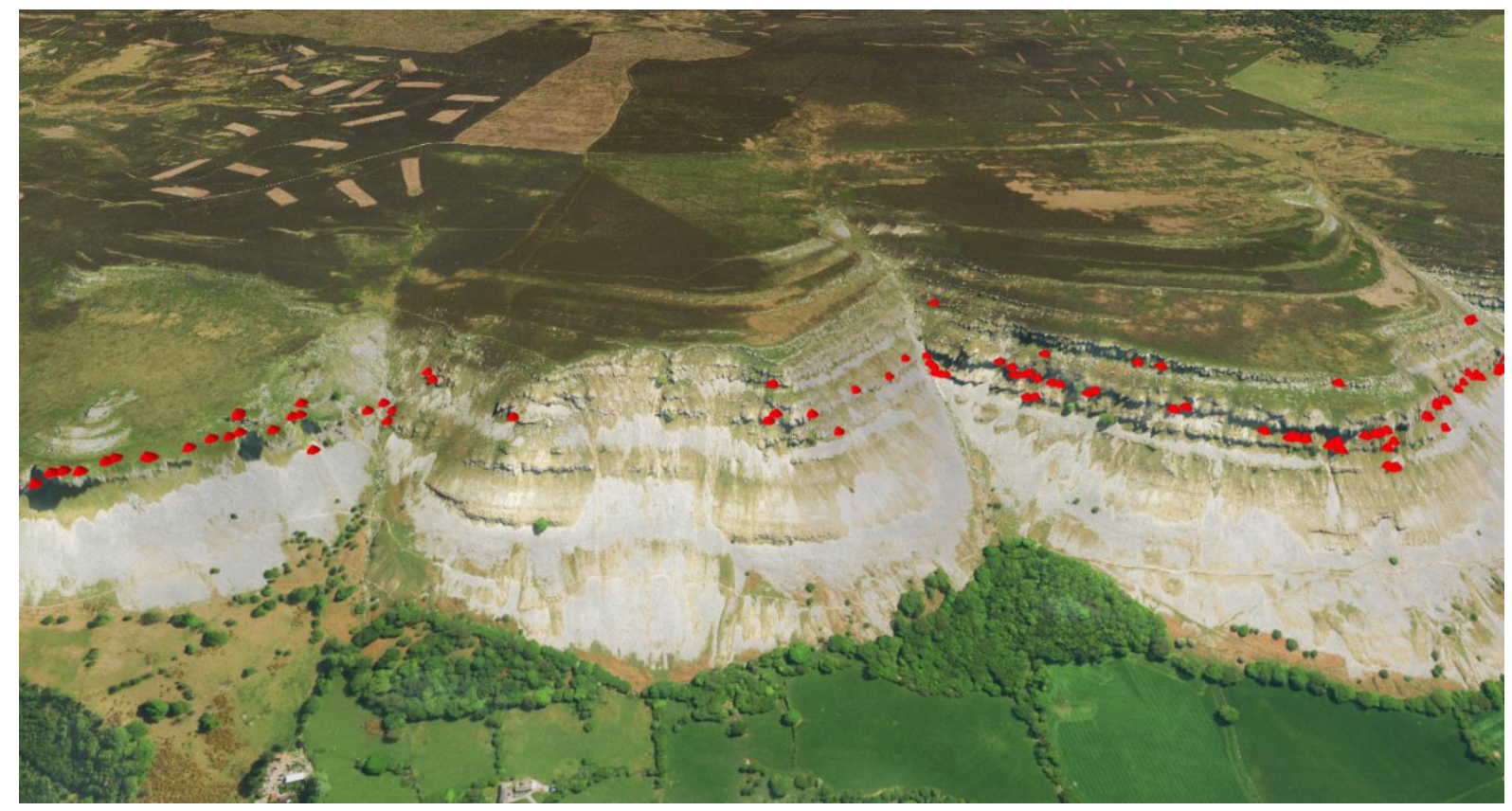

c. mid Craig Tri-Naid-y-Gath to mid Craig Arthur.

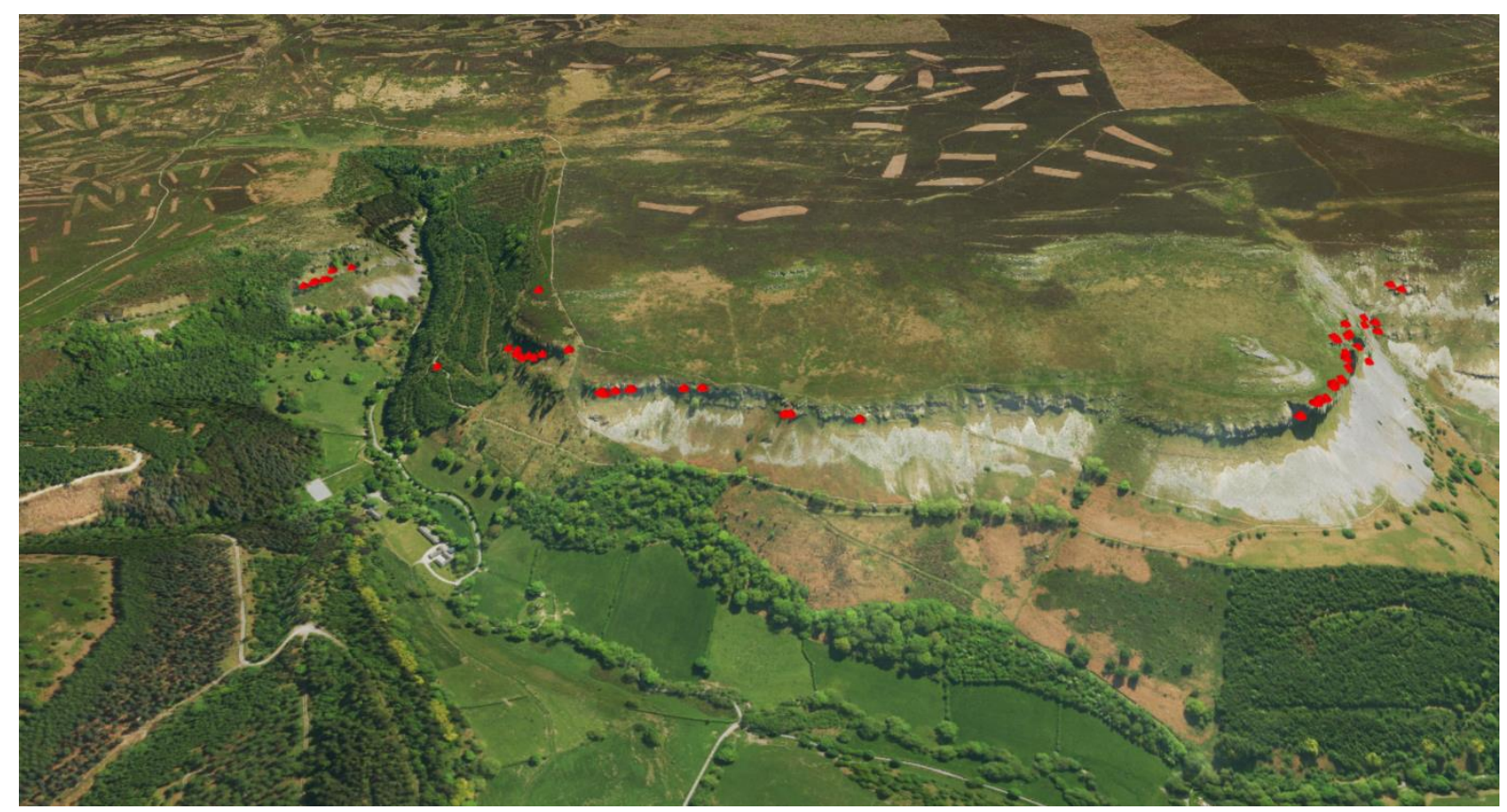

d. Craig Arthur to Craig y Forwyn.

Figure 5a-d. Distribution of Sorbus cuneifolia at Creigiau Eglwyseg in 2017, lateral views ordered from south to north. 


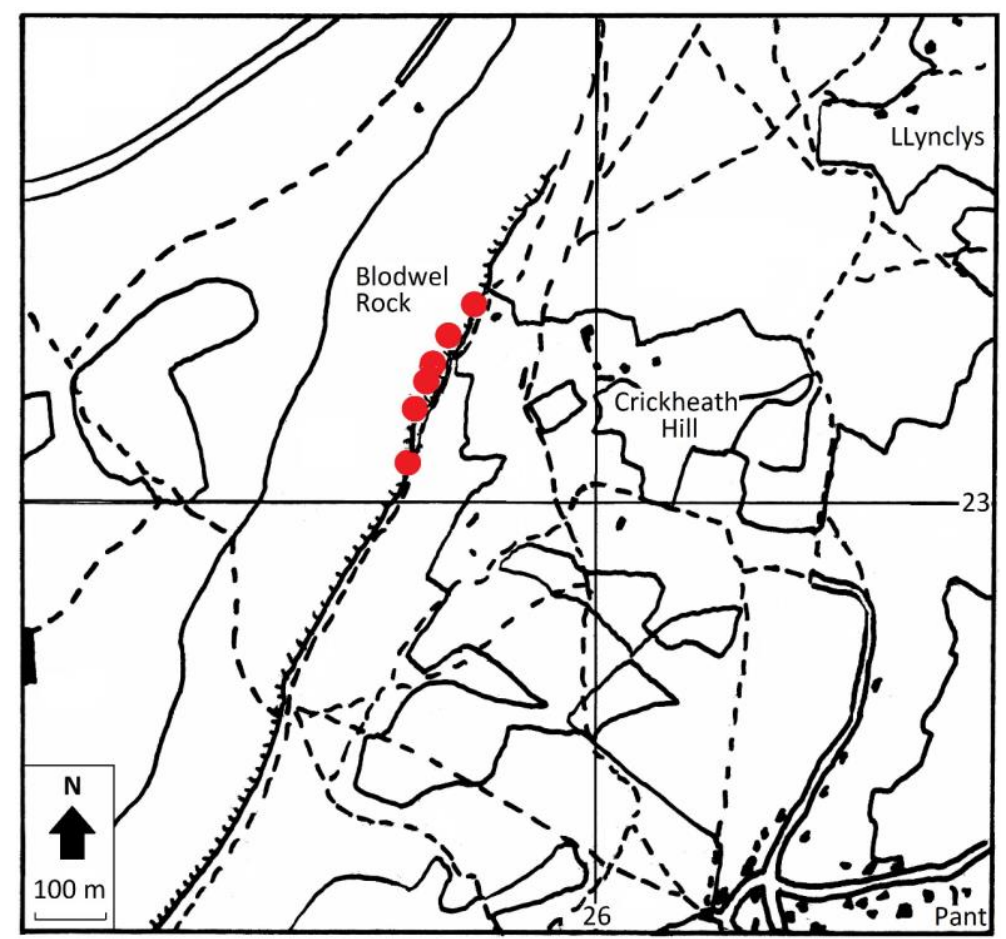

Figure 6. Distribution of Sorbus cuneifolia at Blodwel Rock, Shropshire in 2017.

Tree growth indicators

The heights of $S$. cuneifolia trees are shown in Fig. 7. It grows to an estimated $6 \mathrm{~m}$ tall with an average height of $2.5 \mathrm{~m}(\mathrm{n}=307)$ but with a skewed distribution with few very small trees up to $1 \mathrm{~m}$ tall, a peak of trees about $2 \mathrm{~m}$ tall and then a steadily declining proportion of larger trees.

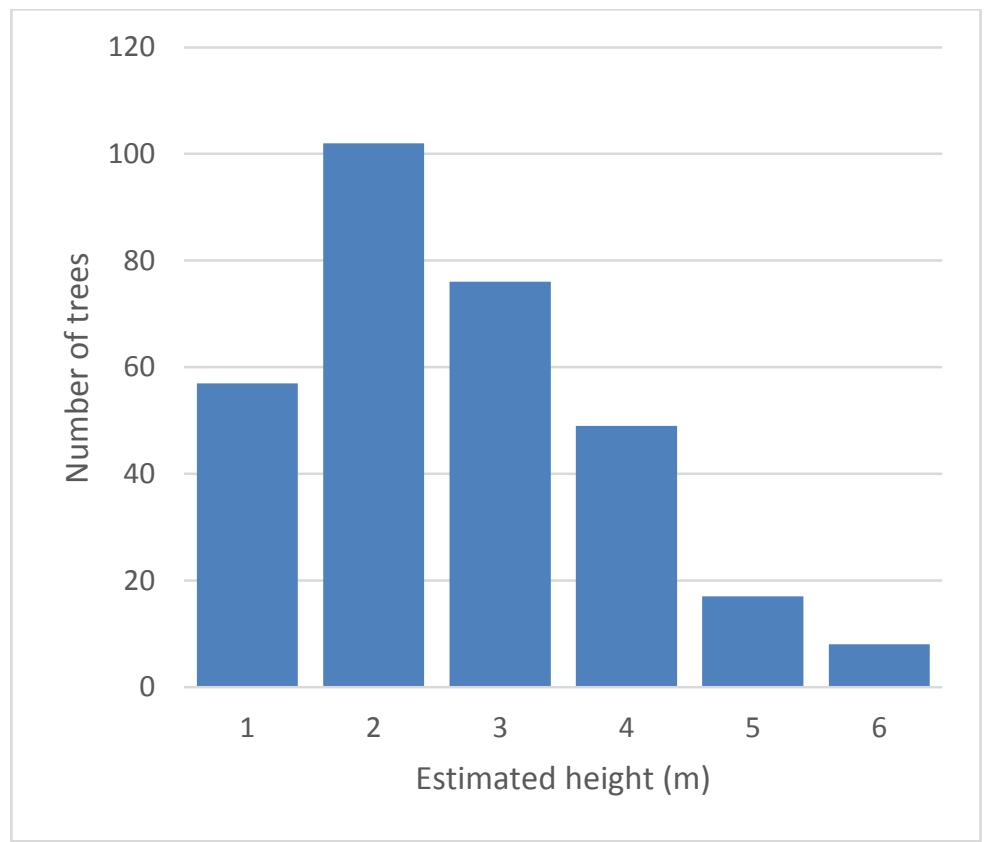

Figure 7. Estimated heights of all trees of $\mathbf{S}$. cuneifolia $(n=307)$. 
On the exposed rocks at Creigiau Eglwyseg trees may lose trunks in winds or snow and re-sprout from the base, and are thus naturally coppiced (29\% of the trees were maidens and $71 \%$ coppiced), hence height is not a good predictor of tree age. When maiden trees only are compared (Fig. 8), there is a higher proportion of young trees which may indicate regular recruitment from seed.

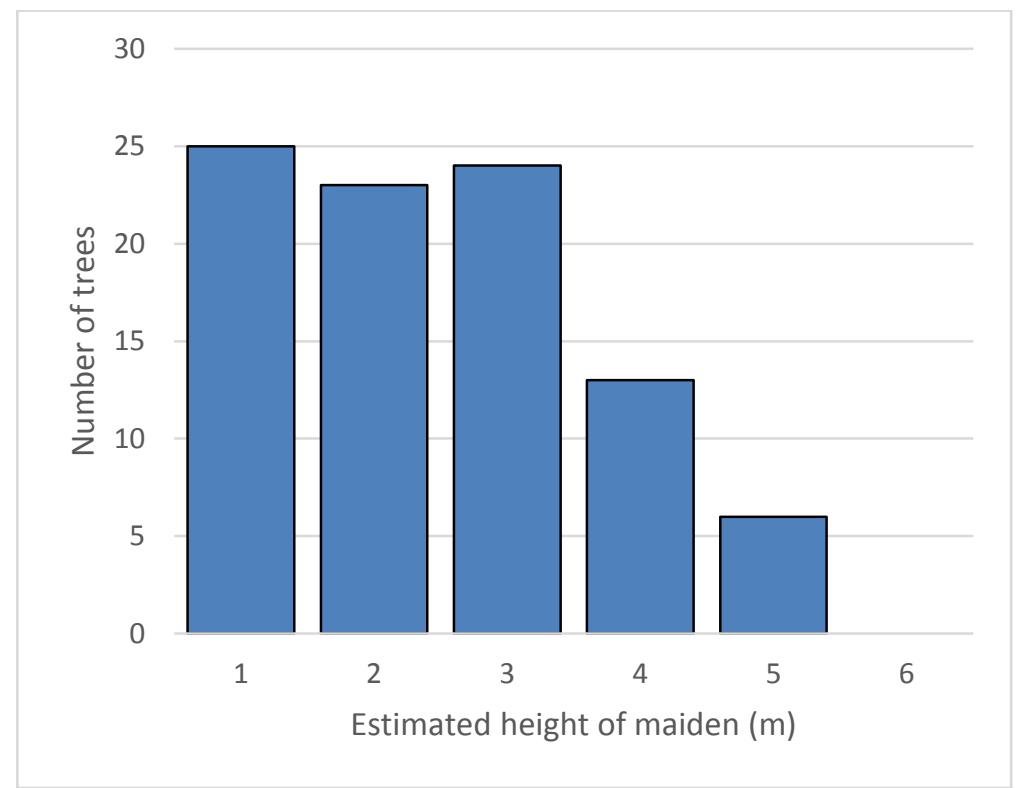

Figure 8. Estimated heights of maiden trees of $S$. cuneifolia $(n=91)$.

2017 was probably a good fruiting year for S. cuneifolia, $66 \%$ of the trees having at least 1 visible fruit. Similar proportions of coppiced trees (63\%) and maidens $(67 \%)$ were fruiting, suggesting coppicing does not affect fruiting significantly. For comparison, only $29 \%$ of $S$. rupicola trees were observed fruiting.

Comparison of 2017 survey with 1987 survey

Both 2017 and 1987 surveys tried to census the entire S. cuneifolia population at Creigiau Eglwyseg which makes a comparison legitimate, despite the difference in personnel and time spent surveying ( 6 days in 1987, 4 in 2017); in practice these probably represent a similar survey effort, particularly as Vicky Morgan mostly worked alone in 1987.

A comparison of the 2017 distribution of S. cuneifolia with that in 1987 as assessed from the trees marked on the photographs (Morgan, 1987) shows that most of the whitebeams were found in similar places in similar proportions. Gaps in distribution south of Dinbren Uchaf, in the centre of Craig-yr-Ogof and east of Craig Arthur were found in both surveys.

Sorbus cuneifolia was recorded more widely to the north and south in 2017 as the 1987 survey did not include Craig y Forwyn at the north end and only recorded as far south as the northern end of the Tan-y-castell quarry; both these sites had old trees in 2017 showing that they would have been present in 1987. A young tree on Offa's Dyke path in 2017 is a new tree. The tree recorded by Morgan (1987) at Castell Dinas Bran was removed in the 1990s. 
The 2017 population estimate of 307 trees is $28 \%$ larger than the 240 trees recorded in 1987 (Table 1). Comparing like-for-like sections, in 2017 more trees were recorded except at Craig Arthur, but the general increase in numbers may simply be due to the survey methods. In 1987 only trees which could be confidently recorded were included, and in 2017 more tiers of cliff were directly accessed so small/young trees not identifiable from a distance may have been better recorded.

Table 1. Comparison of S. cuneifolia populations in 1987 and 2017 for each section. Sections marked 'NS' were not surveyed in 1987.

\begin{tabular}{|l|c|c|}
\hline Section (following Morgan 1987) & $\begin{array}{c}\mathbf{1 9 8 7} \\
\text { counts }\end{array}$ & $\begin{array}{c}\mathbf{2 0 1 7} \\
\text { counts }\end{array}$ \\
\hline Craig y Forwyn (SJ230477 to SJ233482) & NS & 8 \\
\hline Offa's Dyke path (SJ231478) & NS & 1 \\
\hline Worlds End to Ty Canol (SJ230477 to SJ226474) & 19 & 23 \\
\hline $\begin{array}{l}\text { Ty Canol to stream above Tan-y-graig (i.e. Craig Arthur; } \\
\text { SJ226474 to SJ225468). }\end{array}$ & 28 & 26 \\
\hline $\begin{array}{l}\text { Tan-y-graig to stream above Plas yn Eglwyseg (SJ225468 } \\
\text { to SJ224461) }\end{array}$ & 10 & 14 \\
\hline $\begin{array}{l}\text { Plas yn Eglwyseg to stream above Rock Farm (SJ224461 } \\
\text { to SJ222453) }\end{array}$ & 69 & 96 \\
\hline $\begin{array}{l}\text { Rock Farm to gully above Dinbren Uchaf (SJ222453 to } \\
\text { SJ220445) }\end{array}$ & 78 & 87 \\
\hline $\begin{array}{l}\text { Dinbren Uchaf to gully above Dinbren Isaf (SJ220445 to } \\
\text { SJ225440) }\end{array}$ & 35 & 49 \\
\hline Tan-y-castell (SJ225440 to SJ234431) & NS & 3 \\
\hline Castell Dinas Bran (SJ222430) & 1 & 0 \\
\hline & $\mathbf{2 4 0}$ & $\mathbf{3 0 7}$ \\
\hline
\end{tabular}

Part of the increase in numbers could be due to an increase in population but this is not possible to assess as the 1987 survey did not record tree growth data. There were only two clear examples of recruitment in 2017, one dead tree and the removal of one tree from Castell Dinas Bran. Four of the five large trees shown in close-up photos in 1987 were refound in 2017, but the fifth could not be clearly located.

\section{Discussion}

Population sizes

A total of 315 trees of S. cuneifolia were recorded (307 at Creigiau Eglwyseg, 8 at Blodwel Rock) showing it has a good population which is relatively large compared to the populations of other endemic whitebeams (cf. Table 1 in Rich et al., 2010, 
with updates). The $S$. cuneifolia population at Blodwel Rock is larger than previously reported, but is still very small.

Evidence from the tree growth data recorded during the 2017 survey also suggests that the populations of both S. cuneifolia and S. rupicola are healthy. The wide range of tree sizes present are indicative of a wide age distribution in both species, and the high proportions of coppiced trees ( $71 \%$ and $73 \%$ respectively) reflects responses to the exposed, windy, cliff habitat. Interestingly, $66 \%$ of the population of S. cuneifolia was fruiting, more than twice that of S. rupicola $(29 \%)$. Compared to our previous Sorbus surveys where fruiting has been recorded, the $66 \%$ of $S$. cuneifolia trees fruiting was also very high ( $49 \%$ fruiting in S. admonitor, $48 \%$ S. bristoliensis, 47\% S. subcuneata, 54\% S. vexans, Rich et al., 2010).

\section{Tree growth indicators}

Given that height of tree is a very crude proxy measure of age, few firm conclusions can be drawn about the population age structure other than that the wide range of heights present is indicative of a wide age distribution and that recruitment is probably ongoing. The high proportion of $S$. cuneifolia trees fruiting throughout Creigiau Eglwyseg in 2017 was a good indication of a healthy pollination. It also suggests that fruiting is not obviously limited by pollinators or proximity to pollen sources.

\section{Changes since 1987 at Creigiau Eg/wyseg}

The increase in the number of trees of S. cuneifolia at Creigiau Eglwyseg from 240 to 296 (for like-for-like areas) since the 1987 survey is probably mainly due to recording, as $S$. cuneifolia was found in very similar places and in similar proportions to Morgan (1987). The overall increase is probably largely due to a wider area being surveyed, more confident recording of uncertain trees and greater survey access onto small ledges. An increase in the population however cannot be ruled out, as some new regeneration was apparent. The one clear conclusion is that $S$. cuneifolia has not declined at Creigiau Eglwyseg.

\section{Conservation status of Llangollen whitebeam}

Sorbus cuneifolia is confirmed as of IUCN (2001) conservation status 'Endangered', with 198 reproductively mature individuals and a total population of 315 trees in 2 sites, and no evidence of population decline. The global assessment for $S$. cuneifolia as 'Endangered' (Beech \& Rivers, 2017; Rivers et al., 2018) has been confirmed and the details can updated with the 2017 survey findings.

Although globally very rare, there seems no immediate threat to the long term survival of $S$. cuneifolia. At Creigiau Eglwyseg it is clear that widespread sheep grazing restricts the trees to the cliffs, as it presumably has for hundreds of years. A reduction of sheep numbers would allow localised increases in S. cuneifolia, but the population seems healthy overall. The high proportion of fruiting trees indicates good potential for reproduction, and there is plenty of potential habitat for it to spread further on the cliffs. There are many Sorbus trees in popular climbing areas but no direct evidence of damage to the Sorbus trees by climbers. The only obvious potential threat is the spread of the invasive Schedule 9-listed Cotoneaster integrifolius which has already established large populations on the cliffs above Dinbren Uchaf and adjacent areas. 
At Blodwel Rock, the $S$. cuneifolia population is bigger than previously thought and rope access surveys would probably reveal more plants. There are no obvious threats other than longer term succession to tall woodland resulting in shading out of the open rocks.

Both sites are designated as Sites of Special Scientific Interest (SSSI), but as $S$. cuneifolia was described after its sites were designated as SSSIs, it is not cited as a feature of either and has no direct protection; it should thus be added as a feature at the next SSSI revision. A conservation programme to re-establish $S$. cuneifolia at Castell Dinas Bran is in progress and will be reported separately.

\section{Acknowledgements}

We would like to thank the land owners for access permission. The work was supported by Chester Zoo, the Clwydian Range and Dee Valley AONB, Denbighshire County Council and Natural Resources Wales.

\section{References}

Babington, C.C. 1843. Manual of British botany. London: J. van Voorst.

Beech, E. \& Rivers, M.C. 2017. Sorbus cuneifolia. The IUCN Red List of Threatened Species 2017: e.T79748466A79748470. http://dx.doi.org/10.2305/IUCN.UK.2017-2.RLTS.T79748466A79748470.en.

Houston, L., Robertson, A. \& Rich, T.C.G. 2008. The distribution, population size and growth of the rare English endemic Sorbus bristoliensis A. J. Wilmott, Bristol Whitebeam (Rosaceae). Watsonia, 27: 37-49.

Hudson, W. 1798. Flora Anglica. 3rd edition. London.

IUCN 2001. IUCN Red List Categories. Version 3.1. Gland: International Union for Conservation of Nature.

Morgan, V. 1987. Sorbus anglica Clwyd. Unpublished survey report to Nature Conservancy Council.

Rich, T.C.G. \& Proctor, M.C.F. 2009. Some new British and Irish Sorbus L. taxa (Rosaceae). Watsonia, 27: 207-216.

Rich, T.C.G. \& Whild, S.J. 2012. The Whitebeams (Sorbus) of Blodwel Rock. Shropshire Botanical Society Newsletter, 24: 10.

Rich, T.C.G., Houston, L., Robertson, A. \& Proctor, M.C.F. 2010. Whitebeams, Rowans and Service Trees of Britain and Ireland. A monograph of British and Irish Sorbus L. London: Botanical Society of the British Isles in association with National Museum Wales.

Rivers, M., Beech, E., Allen, D., Barstow, M., Window, J., Rich, T. et al. 2018. European Red List of Trees. London: Botanic Gardens Conservation International/Gland: International Union for Conservation of Nature.

Rich, T.C.G., Houston, L. \& Goodwin, A. 2017. Llangollen whitebeam (Sorbus cuneifolia) survey 2017. Unpublished report to Chester Zoo, 9 November 2017.

Copyright retained by author(s). Published by BSBI under the terms of the Commons Attribution 4.0 International Public License.

ISSN: $2632-4970$

https://doi.org/10.33928/bib.2019.01.231 